\title{
A világjárvány és a hibrid hadviselés egyes összefüggései az álhíresztelések terjedésének tükrében
}

\section{SIMICSKÓ ISTVÁN ${ }^{1}$}

\begin{abstract}
A nagyhatalmak közötti versengés egyik legfontosabb eszközévé a hibrid hadviselés vált, amelynek célja a társadalmak meggyengitése közvetlen katonai beavatkozás nélkül. A célpont ország stabilitását a támadó fél a modern tömegkommunikációs eszközöket felhasználva, álhírek terjesztésével, illetve belső ellenzéki csoportosulásokat támogatva igyekszik megtörni. A koronavírus-járvány okozta feszültség a hibrid támadások számára kedvezö közeget teremtett. A megnövekedett veszéllyel szemben a társadalmaknak olyan intézkedéseket kell hozniuk, amelyek hosszú távon szavatolják a biztonságukat.
\end{abstract}

Kulcsszavak: hibrid hadviselés, világjárvány, álhíresztelés

\section{Some Correlations between the Pandemic and Hybrid Warfare in Light of the Spread of Fake News}

Hybrid warfare has become one of the most important means in the competition between the great powers; it aims to weaken societies without direct military intervention. The attacking party seeks to break the stability of the target country by using modern mass communication to spread fake news and supporting internal opposition groups. The tension caused by the coronavirus epidemic has created a favorable environment for hybrid attacks. In the face of increased danger, societies need to ensure their longterm security with proper institutions.

Keywords: hybrid warfare, pandemic, fake news

\section{Bevezetés}

A globalizáció folyamatos térnyerésével és az egypólusú világrend átalakulásával egyre nyilvánvalóbb az a nagyhatalmi verseny, amely az USA, Kína

1 A KDNP Országgyűlési Képviselőcsoportjának frakcióvezetője, egyetemi oktató. 
és Oroszország között bontakozik ki, és amellyel a belátható jövőben a legkomolyabb konfliktusforrásként kell számolnunk. Ezen összecsapások megjelenésében és lefolyásában várhatóan egyre nagyobb teret nyer a szakirodalom által hibridnek nevezett hadviselési forma, amelynek alkalmazására a közelmúltból több példát is kiemelhetünk: az „Arab tavaszt”, a Krím-félsziget annektálását eredményező orosz-ukrán konfrontációt vagy a kínai érdekszféra tengeri kiterjesztését célzó komplex műveleteket.

A világméretűvé szélesedett koronavírus-járvány (Covid-19), és annak jelenleg belátható társadalmi és gazdasági következményei már most gondolkodásra kell hogy sarkallják a felelős döntéshozókat, hogy a többek között a hibrid hadviselés elleni védelmet is szolgáló stratégiák ebben a megváltozott környezetben mennyire lehetnek hatékonyak. Továbbá ezzel szoros összefüggésben a járvány okozta válsághelyzet tapasztalatai mentén át kell tekinteni a társadalmak védekezőképességét az angolszász terminológiából átvett kifejezéssel élve „fake news”-zal, azaz álhíresztelésekkel szemben, amelyet elsődlegesen a modern média minden korábbinál szélesebb körü és szerteágazóbb használata tesz lehetővé, és amely a hibrid hadviselésnek is kulcsfontosságú eleme.

\section{Néhány gondolat a hibrid hadviselésről}

A hibrid hadviselés a William S. Lind által alkalmazott generációs megközelités szerint az újkori hadviselési formák negyedik nemzedékéhez tartozik. ${ }^{2}$ A világban a nagyhatalmak által felhalmozott tömegpusztító fegyverek mennyisége és tűzereje olyan méreteket öltött, hogy nyílt háború esetén ezek bevetésekor a hátország infrastruktúrája és lakossága valószínűleg belátható időn belül helyrehozhatatlanul katasztrofális pusztítás áldozatául esne. Az ettől való félelem már az Amerikai Egyesült Államok és a Szovjetunió hidegháborújában is olyannyira elrettentette a feleket egymás közvetlen, nyílt és átfogó megtámadásától, hogy szerencsére erre nem került sor. Ez a félelem ma is létezik, éppen ezért a hadviselés súlypontja az indirekt eszközök felé tolódott el.

Szun-Ce $A$ hadviselés törvényei címủ művében fogalmazta meg azt az alapvető fontosságú stratégiai szemléletet, amelyből véleményem szerint a hibrid hadviselés alapgondolata is táplálkozik: „Nem is harcolni, mégis alávetni az ellenséges sereget: ez a legjobb a jók között. Így aki igazán ért a hadviseléshez, úgy töri meg az idegen sereget, hogy nem vív csatát vele [...]"3 A hibrid hadviselés fó jellemzője a béke és a háború közötti határ elmosódása, továbbá, hogy nincs felismerhetö harctér, és nemzetközi jogi értelemben véve nincs hadüzenet sem. A hibrid hadviselést alkalmazó támadó fél fő célja az akaratának rákényszerítése, a kifárasztás, a megtámadott fél ellenállási képességének megtörése, mielött a katonai erő nyílt alkalmazására kerülne sor.

2 William S. Lind: The Changing Face of War: into the Fourth Generation. Marine Corps Gazette, 73. (1989), 10. 22-26.

3 Szun-Ce: A hadviselés törvényei. (Fordította: Tõkei Ferenc) Elérhető: https://mek.oszk. hu/01300/01345/01345.htm (A letöltés dátuma: 2020. 04. 22.) 
A szakirodalom olyan tényezőket nevesít, amelyek a hibrid hadviselés vonatkozásában különös kockázattal bírnak, és amelyek annak eszközeivé lehetnek. ${ }^{4}$ Ilyen például többek között a modern információs és kommunikációs technológiák alkalmazása, radikális társadalmi csoportok külső finanszírozása és irányítása, valamint az ország társadalmi-politikai helyzetének destabilizálására törekvő politikai erők és mozgalmak támogatása. E bomlasztó törekvések elsődleges végrehajtói a háttérből irányított álcivilek, tüntetők, kormányellenes szervezkedők, amelyek célja, hogy problémák felnagyításával, a társadalmi törésvonalak kiszélesítésével, belső politikai feszültség szításával igyekeznek káoszt és elégedetlenséget teremteni a hátországban. Ez nem új jelenség. A történelemben a propaganda, a félrevezetés, a szabotázs, a bomlasztás mindig is a hadviselés részei voltak. Korábban viszont sosem volt olyan mértékủ globalizált kapcsolatrendszer és technológia, amely lehetővé tenné a hatékony hibrid hadviseléshez elengedhetetlen gyors helyzetfelismerést és közvetlen irányítást, a komplex müveletek precíz végrehajtását, továbbá a kiterjedt stratégiai kommunikációt.

Valerij Geraszimov vezérezredesnek, az Orosz Föderáció Fegyveres Erői vezérkari főnökének 2013-as és 2019-es nyilatkozatait ${ }^{5}$ elemezve, a nevével fémjelzett hibrid hadviselési modell szerint először a támadó fél felméri a célország sebezhető pontjait, különös tekintettel a közigazgatására, gazdaságára, társadalmára és haderejére, majd létrehozza az érdekeit képviselő civil és politikai szervezeteket, az „ötödik hadoszlopot", továbbá megerősíti pozícióit a médiában. A feszültségkeltés fontos eleme az etnikai, vallási és társadalmi ellentétek gerjesztése, a központi kormányzattal szembeni elégedetlenségi mozgalmak támogatása a célország destabilizálása érdekében, amely során nagy hangsúlyt kapnak a hírszerzési eszközök, amelyek útjában nem állnak a nemzeti határok. Ezzel kombináltan a támadó nagy hatótávolságú precíziós csapásokat mér a kulcsfontosságú célpontokra. A támadó végül politikai, diplomáciai, gazdasági nyomással, zavargások keltésével fokozza a feszültséget, és mélyíti el a belső válságot, amelyet stratégiai céljainak megfelelően katonai megszállással vagy hozzá lojális politikai vezetés hatalomra segítésével tetéz be a megtámadott országban. Geraszimov ezt a taktikát 2019-ben már szemléletes módon „trójai faló”-nak nevezte, és az Amerikai Egyesült Államok, illetve Venezuela relációjában vizionálta az egyik lehetséges jövőbeli alkalmazási területét.?

4 Simicskó István: A hibrid hadviselés előzményei és aktualitásai. Hadtudomány, (2017), 3-4. 3-16.

5 Pavel Felgenhauer: A New Version of the 'Gerasimov Doctrine'? Eurasia Daily Monitor, 16. (2019), 32. Elérhető: https://jamestown.org/program/a-new-version-of-the-gerasimov-doctrine/ (A letöltés dátuma: 2020. 04. 22.)

6 Az angolszász terminológa szerinti fifth column, azaz ötödik hadoszlop kifejezést a lakosok egy csoportjára értjük, akik támogatják az ország ellenségeit és titokban segítik őket (Cambridge Dictionary).

7 Valerij Geraszimov Orosz Hadtudományi Akadémián (Академия военных наук Российской Федераиии) elhangzott beszéde. Krasnaya Zvezda, 2019. 03. 04. Elérhető: http://redstar.ru/vektoryrazvitiya-voennoj-strategii/?attempt=2 (A letöltés dátuma: 2020. 04. 28.) 
Egyetértek Rácz Andrásnak a hibrid hadviselés által megteremtett új körülményekre tett megállapításával, miszerint a nem katonai eszközök ereje „hatékonyságban [...] gyakran meghaladja a fegyverek erejét". Ugyanis a támadó a megtámadott állam létfontosságú alrendszereinek súlyos gyengeségeit célozza meg, ezáltal a fegyveres erők korlátozott alkalmazása magát a konfliktust nemhogy nem korlátozza, de politikai, információ-technológiai, gazdasági és diplomáciai eszközökkel kiterjeszti azt a célpont teljes hátországára.

A hibrid fenyegetés kérdésével az Európai Unió is évek óta foglalkozik. Az Európai Bizottság meghatározása szerint ilyennek minősülnek a kényszerítő és felforgató tevékenységek, valamint a hagyományos és nem hagyományos módszerek (például katonai, diplomáciai, gazdasági, technológiai) egyvelege, amelyeket állami vagy nem állami szereplők összehangolt módon használhatnak fel bizonyos célok elérése érdekében úgy, hogy eközben a hivatalosan deklarált hadviselés szintje alatt maradnak. A hangsúly általában a célállam sebezhető pontjainak kihasználásán, valamint egy olyan, nem egyértelmủ helyzet megteremtésén van, amelynek célja a döntéshozatali folyamatok hátráltatása. A hibrid fenyegetések eszközei lehetnek erőteljes félretájékoztatási kampányok is, amelyek során a közösségi médiát használják fel a politikai narratíva befolyásolása vagy közvetítő szereplők radikalizálása, toborzása és irányítása céljából. ${ }^{9}$

\section{A társadalom sebezhetősége}

A történelem során nem állt fent még olyan állam, amelyben ne létezett volna sérülékeny pont valamely társadalmi alrendszerben, a közigazgatásban, a gazdaságban vagy az infrastruktúrában. Minden országban létezik valamilyen szintű belső elégedetlenség, például az egyes társadalmi csoportok között meglévő egyenlőtlenség miatt, de idesorolhatjuk akár a politikai nézetkülönbséget is az egész társadalmat érintő, a nemzet életét befolyásoló fontos közéleti kérdésekben. Előbbi tekintetében példaként a kisebbségek helyzetét lehet említeni, amely számos európai országban komoly belső feszültség forrása. Utóbbira markáns példa a spanyol és a brit állampolgárok hozzáállása a katalán függetlenségi törekvésekhez, illetve a brexithez, de az illegális migrációval kapcsolatos általános vélekedés is idesorolható.

Az egyes társadalmi alrendszerek is lehetnek elégedetlenség forrásai. Ilyen tipikusan a vallás, a társadalom struktúrája, a jogi és igazságszolgáltatási rendszer vagy az etnikai összetétel. Infrastrukturálisan a víz- és energiaellátást, logisztikai, kommunikációs és szállító infrastruktúrákat, az iskolákat és az egészségügyi ellátást emelhetjük ki. A koronavírus-járvány következtében Európa-szerte, de főleg

8 Resperger István: A válságkezelés és a hibrid hadviselés. Budapest, Dialóg Campus, 2018.

9 Közös közlemény az Európai Parlamentnek és a Tanácsnak: A hibrid fenyegetésekkel szembeni fellépés közös kerete. Európai Bizottság, Brüsszel, 2016. április 6. Elérhető: https://eur-lex.europa.eu/legal-content/HU/TXT/PDF/?uri=CELEX:52016JC0018\&from=EN (A letöltés dátuma: 2020. 04. 22.) 
Spanyolországban és Olaszországban túlterheltté vált egészségügyi ellátórendszerrel szemben vagy a járvánnyal kapcsolatos védekezés érdekében megtett intézkedések vonatkozásában a kormányzatokkal szemben megfogalmazott állampolgári elvárások komoly belső feszültséget generáltak. Ugyanitt megemlíthetjük a járvány miatt számos országban életbe lépett rendkívüli jogrendet ${ }^{10}$ vagy a katonai elem megjelenését a stratégiailag fontos vállalatok mủködésében, amelyek külső és belső kritikájának élét jellemzően a demokratikus értékek csorbításának vádja, illetve az állampolgári szabadságjogok korlátozhatóságának mértéke adja. Egy beilleszkedésre nem képes vagy arra hajlandóságot nem mutató etnikai kisebbség is sebezhetővé teszi az adott társadalmat, és folyamatos feszültség forrása lehet, utalva például a franciaországi muszlimokkal kapcsolatos, időről időre fellángoló zavargásokra.

Az egyes országok megélni és megoldani próbált vagy jobb híján elfedni és hordozni kényszerült problémái jelentőségüket és hatásukat tekintve lehetnek hajszálrepedések vagy mély szakadékok az adott ország társadalmában, a hibrid hadviselő fél azonban minden esetben lehetőségként, a stratégiai célok elérése érdekében felhasználható eszközként tekint ezekre. A támadó azonosítja a célország alrendszereinek sebezhető pontjait, majd a rendelkezésére álló eszközökkel, gazdasági vagy politikai nyomásgyakorlással, médiakampánnyal mér csapást, igyekszik belső ellentéteket és elégedetlenséget kelteni, valamint a hazai és nemzetközi közvéleményt befolyásolni.

Ugyanakkor kijelenthető, hogy minél felkészültebb egy társadalom, és minél nagyobb a védekezőképessége, annál kevesebb a kockázata annak, hogy az alrendszereiben megbúvó törésekre épülő, sikeres támadás célpontja lesz, illetve egy társadalom megfelelő felkészültsége pedig a hibrid támadó mủveletek hatékonyságát ronthatja le kritikus időben és mértékben.

\section{4. Álhíresztelés mint a hibrid támadás eszköze}

Orosz szakértők szerint a jövő háborújának legfontosabb hadszíntere az emberi elme lesz. ${ }^{11}$

A Régiók Európai Bizottsága az online dezinformáció kezelésével kapcsolatban egy 2019-ben kiadott véleményében ${ }^{12}$ felhívta a figyelmet, hogy az utóbbi éveknek a globális médiakörnyezetben bekövetkezett változások társadalmi és politikai életre gyakorolt hatásaira, különös tekintettel arra, hogy a közösségi média vált az emberek közötti elsődleges kommunikációs csatornává, amelyet az európaiak több mint fele már most is napi rendszerességgel vagy hetente többször használ, amit a 2020-as

10 A koronavírus (Covid-19) megjelenése és terjedésének megindulása következtében Magyarország Kormánya 2020. március 11-én a 40/2020. (III. 11.) Kormányrendelettel „az élet- és vagyonbiztonságot veszélyeztető tömeges megbetegedést okozó humánjárvány következményeinek elhárítása, a magyar állampolgárok egészségének és életének megóvása érdekében Magyarország egész területére" veszélyhelyzetet hirdetett ki Magyarországon.

11 Jójárt Krisztián: A hibrid hadviselés és a jövő háborúja. Honvédelmi Szemle, 148. (2020), 1. 5-19.

12 A Régiók Európai Bizottsága véleménye - Európai megközelítés az online dezinformáció kezelésére (2019/C 168/04). 
koronavírus-járvány tovább fokozott. Ez azt jelenti, hogy e felületek alkalmazói elvileg milliós nagyságrendű felhasználót érhetnek el közvetlenül az átadni kívánt információval.

E trend egyik jól kimutatható negatív következménye, hogy a közösségi médiában a szerző azonosítása gyakran komoly nehézségbe ütközik, és akár téves információk is villámgyorsan juthatnak el széles tömegekhez. Ezzel ellentétben, a klasszikus orgánumokban, a nyomtatott sajtóban, a rádióban és a televízióban újságírók és szerkesztők vállalnak felelősséget a közvetített tartalmakért. Ez a felelősség az anonimitás gyakorlatára épülő közösségi médiában hiányzik, éppen ezért a hitelességet más esetben biztosító szabályok, jogi garanciák és szokások itt nem érvényesülnek megfelelően.

A Bizottság különös aggodalommal állapította meg, hogy a közösségi média felületei a dezinformáció és a politikai, gazdasági és társadalmi manipuláció eszközeivé váltak a külső és belső szereplők kezében egyaránt, továbbá rendkívül aggasztó jelenségként azonosította, hogy a közösségi média felhasználóinak alapvető problémái vannak a közösségi felületen megjelenő információk megalapozottságának és megbízhatóságának megítélésével. A dezinformációt már most a jövőbeli hadviselés egyik legveszélyesebb fegyverének nevezte, és fellépést sürget az olyan közösségi médiacsatornákon keresztül folytatott propagandával szemben, amely veszélyezteti a társadalmi kohéziót.

A média minden korábbinál szélesebb körűbb használata a hibrid hadviselés nélkülözhetetlen eleme. A médián keresztül dezinformációk és álhíresztelések terjesztésével zavar kelthető a megtámadott ország lakossága körében, így a félretájékoztatott és az „ötödik hadoszlop” által manipulált lakosságon keresztül pedig belső, a propaganda-hadjáratnak, hamis információknak, diplomáciai műveleteknek szintén áldozatul esett nemzetközi közvéleményen keresztül pedig külső politikai nyomás helyezhető a hatalmon lévő kormányra.

\section{Védekezési lehetőségek a hazugságkampányokkal szemben}

Az álhíresztelések elleni hatékony védekezés lehetőségeit véleményem szerint az álhíresztelések alapját képező társadalmi sajátosságokból kiindulva két csoportban szükséges vizsgálni: megkülönböztethetünk az álhíreszteléseket szankcionáló, a tényállás megvalósításától elrettentő jogi eszközöket, illetőleg az álhíresztelést tulajdonképpen hosszú távon okafogyottá, értelmetlenné tévő nevelési eszközöket.

A véleménynyilvánítás szabadságát a legtöbb országban az alkotmány garantálja csakúgy, mint Magyarországon is az Alaptörvény tartalmazza ennek az alapvető szabadságunknak a védelmét. Emellett a médiaszolgáltatásokról és a tömegkommunikációról szóló 2010. évi CLXXXV. törvény pedig rögzíti a szerkesztői szabadságot, amelynek keretében a médiaszolgáltatók szabadon dönthetnek a hírszerkesztés és a hírek megválasztása tekintetében is. Magyarországon a Nemzeti Média- és Hírközlési Hatóság az internetes felületeken megjelenő álhírek vagy gyülöletkeltő tartalmak aspektusait vizsgálva jogi értelemben különbséget tett az uszító, gyülöletkeltő tartalom 
és az álhírek jelensége között, utóbbiról megállapítva, hogy annak vizsgálatára nincs jogköre, hiszen „cenzori” hatáskört jelentene az, hogy eldöntse egy hírről, hogy igaz-e vagy hamis. ${ }^{13} \mathrm{~A}$ valótlan tényállítások vizsgálatára így hazánkban kizárólag a bíróságok rendelkeznek hatáskörrel sajtó-helyreigazítási per keretében, illetőleg a büntető szakágban rémhírterjesztés vádjával eljárva.

A magyar Országgyủlés a koronavírus elleni védekezésről törvényt alkotott, amelyben a rémhírterjesztés büntetőjogi tényállását igazította a járványhelyzethez. A 2020. évi XII. törvény indokolása ${ }^{14}$ hangsúlyozza, hogy a társadalom tömegei érzékenyebbek a járvánnyal kapcsolatos zavar és nyugtalanság keltésére alkalmas téves információkra. A jogalkotó szerint az egész országot kimerítő védekezéssel összefüggésben a szólásszabadság nem terjedhet ki a tudottan valótlan tények állítására, híresztelésére. Nagyon fontos tételt rögzít a jogszabály indokolása, amikor kimondja, hogy a koronavírus-járvány idején hirdetett veszélyhelyzet az ország egészét érinti, a védekezéssel érintett kormányzati intézkedések a társadalom teljes spektrumát átfogják az egészségügytől, az oktatás és a határforgalom korlátozásán keresztül a gazdasági intézkedésekig, éppen ezért a fokozott büntetőjogi védelem indokolt annak érdekében, hogy a veszélyhelyzet elhárítását célzó védekezés eredményességét a valótlan és ezért zavarkeltő tények állítása, híresztelése se hátráltathassa. Ugyanakkor azt is rögzítették, hogy a büntetőjogi arányosság alkotmányos követelménye megkívánja, hogy a védekezés eredményességének megzavarására sem alkalmas, és ezért a köznyugalomra objektíve hatást nem gyakorló állítás ne legyen büntetendő.

Amint arról korábban szóltunk, a társadalom dezinformálása a hibrid hadviselés egyik kiemelkedöen fontos és veszélyes eszköze, de - utalva a törvényhozó által megfogalmazottakra - meg kell állapítsuk, hogy a belső káosz nem csupán egy külső támadás elleni védekezés esélyeit csökkenti, de a járvány elleni védekezés hatékonyságát is rombolhatja. Abból kiindulva, hogy a járványhelyzet időbeli lefolyása jelenleg nem meghatározható, ez a körülmény mindenképpen már rövid távon is eredménnyel kecsegtető, azonnali beavatkozást igényelt. A Büntető Törvénykönyv módosítása teljes mértékben megfelel e szempontnak.

Hosszú távon azonban álláspontom szerint mindenképpen szükséges a társadalom önvédelmi képességének kifejlesztése az ország érdekeivel ellentétes álhíresztelések ellen. Mivel a hibrid hadviselésben nincs deklarált háború, ezért nem is lehet hagyományos módon fellépni ellene, csak indirekt módon lehet válaszolni. Mind a társadalmat bomlasztó, belülről gyengítő hibrid műveletekkel szemben, mind pedig a jelenlegihez hasonló veszélyhelyzet hatékony kezelése érdekében tartós megoldást jelenthet a társadalom hazafias nevelése. Az állampolgárok részére szóló oktatási

13 A médiahatóság mozgástere az internetes felületeken megjelenő álhírek vagy gyülöletkeltố tartalmak esetén, különösen választási kampány idején. 2018. NMHH Médiajogi háttéranyag. Elérhető: http:// nmhh.hu/cikk/194513/A_mediahatosag_mozgastere_az_internetes_feluleteken_megjeleno_alhirek_vagy_gyuloletkelto_tartalmak_eseten_kulonosen_valasztasi_kampany_idejen (A letöltés dátuma: 2020. 04. 22.)

14 T/9790. számú törvényjavaslat indokolása. Elérhető: www.parlament.hu/irom41/09790/09790.pdf (A letöltés dátuma: 2020. 04. 27.) 
programok bevezetése az Európai Bizottság az online dezinformáció elleni küzdelem stratégiájának is fontos pillére. ${ }^{15}$

A hazafiasság elsődlegesen a hazához, a haza értékeihez való érzelmi kötődést jelenti. Ennek az érzelmi köteléknek a kialakítását és megszilárdítását szolgálja a közös nyelv, a kultúra, a hagyományok megismertetése és ápolása, amely végső soron hozzájárul a nemzeti öntudat kialakulásához. Ha az ember érdeklődik szülőföldje iránt, érzelmileg kötődik hozzá, azzal olyan érték hordozójává válik, amely gyökeret, stabilitást jelenthet a mindennapok küzdelmeiben is. Ha pedig kialakul a hazaszeret érzése, akkor ez tevékeny törődéssé is alakítható, és amennyiben hazánkat bármilyen veszély fenyegeti, akkor sokkal könnyebben működik a társadalom önvédelmi reakciója, ami ebből az érzésből fakad. A hazaszerető társadalom és azok alrendszerei kevésbé sebezhetők a bomlasztó, lejárató, stabilitást veszélyeztető törekvésekkel szemben, mint amilyen egy nyilvánvalóan politikai érdekek mentén kibontakozó és súlyos károkkal fenyegető hazugságkampány.

\section{A világjárvány megítélése a hibrid hadviselés szemszögéből}

A biológiai hadviselés nem új vívmány az emberiség történelmében. Mára számolni kell azzal, hogy a kórokozókat vagy különféle mérgeket a hadseregek, terroristák vagy bűnözők is alkalmazhatják, amelynek célpontjai éppúgy lehetnek emberek, állatok vagy növények. A napjainkban is élő fenyegetés komolyságát hangsúlyozza, hogy az Európai Bizottság 2017-ben a vegyi, biológiai, radiológiai és nukleáris biztonsági kockázatokkal szembeni uniós szintű felkészültség és reziliencia megerősítésére irányuló cselekvési tervet ${ }^{16}$ is készített, amellyel kapcsolatban rámutatott a vegyi és biológiai biztonsági kihívások jelentőségére. Ebben rögzítették többek között a különleges biztonsági fenyegetést jelentő vegyi anyagok jegyzékének kidolgozására, a fenyegetések észlelésének javítása érdekében a fenyegetettségi forgatókönyvek felülvizsgálatára és a meglévő kimutatási módszerek elemzésére, továbbá az alapvető egészségügyi ellenintézkedések, laboratóriumi, kezelési és egyéb kapacitások számbavételére való törekvést. A dokumentum igazi élét az adja, hogy az Európai Unió, mint mérvadó nemzetközi szereplő a legmagasabb szinten számol a veszéllyel és sürgeti a felkészülést.

Az új típusú koronavírus-járvány kezdetével kapcsolatban mindeddig ellentmondásos információkra és találgatásokra tudunk hagyatkozni. A hivatalos közlemények csupán arról szólnak, hogy az Egészségügyi Világszervezet kínai irodája a közép-kínai Hubei tartományának székhelyén, Wuhanban ismeretlen eredetü tüdőgyulladásos megbetegedéseket regisztrált, amelyek okozójaként a kínai hatóságok 2020. január

15 A Régiók Európai Bizottsága véleménye (2019/C 168/04) i. m. (12. lj.).

16 A védelmet nyújtó Európa: az Unió a reziliencia kialakitására és a hibrid fenyegetésekkel szembeni hatékonyabb fellépésre törekszik. 2018. Elérhető: https://ec.europa.eu/commission/presscorner/detail/hu/IP_18_4123 (A letöltés dátuma: 2020. 04. 27.) 
7-én a SARS-CoV-2 elnevezésủ, új típusú koronavírust azonosították. ${ }^{17}$ A járvány négy hónap alatt lényegében az egész világon elterjedt, több millió megbetegedést és több százezer halálesetet okozva, továbbá a hibrid hadviselés szempontrendszerét alapul véve jelentősen próbára tette az egyes országok stabilitását és társadalmi alrendszereinek, lakosságának tűrőképességét. A megbetegedés kialakulásával kapcsolatban mindeddig nincs biztos tudományosan alátámasztott magyarázat.

A járvány következményeit vizsgálva a legfontosabb megállapítás, hogy a betegség terjedésének és lefolyásának sajátosságai kiemelt terhet rónak az egészségügyi ellátórendszerre a rendkívülinek nem minősülő helyzetekben előfordulónál jelentősen nagyobb számú, intenzív kezelést igénylő beteg ellátása okán. Az emberéleten és a gazdaságon túl a járvány az egészségügybe és a kormányok cselekvőképességébe vetett bizalmat is megtámadta. Tekintettel arra, hogy a vírussal szemben hatásos gyógyszert ma még nem fejlesztettek ki, az egyes országok a társadalom életét alapjaiban érintő intézkedésekkel, például hatósági karanténnal, kijárási korlátozással, rendezvények betiltásával, illetve a kereskedelmi egységek nyitvatartásának szabályozásával, továbbá széles körü tájékoztatással védekezhetnek a terjedés ellen.

A hatékony védekezésnek fontos sarokköve ugyanakkor a vezetőket övező közbizalom. A járvánnyal kapcsolatban megnövekedett dezinformáció, amely a Büntető Törvénykönyv magyarországi szigorítását is inspirálta, súlyos károkat okoz azzal, hogy bizalmatlanságot gerjeszt a kormányok iránt, ugyanis az emberek kételkedni kezdenek az intézkedések hatékonyságában, lazul a társadalom fegyelme a megelöző intézkedések végrehajtása iránt, amely viszont tovább rontja a járvány hatásait, a negatív tendenciák pedig tovább rombolják a vezetők hitelességét, mintegy igazolva az álhíreszteléseket. Tulajdonképpen a járvány és a hazugságkampány együtt egy öngerjesztő folyamatot jelent, amelyben a kormányok végső soron az elégedetlenség növekedésével, külső és belső nyomással, gazdasági visszaeséssel, tehát összességében egyre szűkülő cselekvési lehetőségekkel, egyre zsugorodó mozgástérrel kénytelenek szembesülni. Az álhírek elhintik a bizalmatlanság magvait, a járvány miatt destabilizálódott társadalmak „városkapuján” pedig már be is húzták Geraszimov tábornok „trójai falovát”.

Egy hatalom számára a koronavírus-járvány nagyszerü lehetőség az emberiség ellenőrzésére, a gazdasági pozíciók javítására, a rivális vagy célpont országok védekezőképességének tesztelésére vagy sorsfordító politikai változások kieszközlésére, például választások előtt a közbeszéd tematizálásával. A betegséggel kapcsolatos pánik létrehozásával és támogatásával közvetlenül befolyásolható más országok politikája és gazdasága. Ezenfelül ez az eszköz segít megtörni az uralkodó értékrendszert, valamint a félelem és pánik légkörében élő embert könnyebb ellenőrizni. A koronavírus-járvány több sajátossága és eddigi tapasztalatai arra utalnak tehát, hogy egy ilyen pandémia a hibrid hadviselés egy tipikus példája is lehet.

17 Tájékoztató az új koronavírusos (Covid-19) megbetegedésekkel kapcsolatban. 2020. Elérhető: https:// konzuliszolgalat.kormany.hu/koronavirus (A letöltés dátuma: 2020. 04. 27.) 
Ezt a feltevést megerősíteni látszik, hogy az Amerikai Egyesült Államok és Kína retorikájában is tetten érhető a hibrid hadviselésre való utalás, és egymás burkolt vádakkal való illetése. Trump amerikai elnök következetesen „kínai vírusnak” nevezi a koronavírust, ${ }^{18} \mathrm{Hszi}$ Csin-ping kínai elnök pedig a világjárványt háborúként aposztrofálja, amely ellen ellentámadást - megfogalmazása szerint „népi háborút” - kell indítani, ${ }^{19}$ mintegy utalva arra, hogy ezt a harcot nem hadseregek, hanem leginkább a hétköznapi ember szintjén kell megvívni.

\section{7. Összegzés}

A hibrid hadviselés legnagyobb kockázata abban rejlik, hogy nehéz felismerni, pontosan mi történik. Nincs hadüzenet, a hadviselő felek kiléte nem egyértelmű, ezáltal a hibrid támadásnak kitett állam kormánya és a nemzetközi közösség csak követni tudja az eseményeket, és a reakciók jellemzően elkésettek. Mivel túl sok a bizonytalanság, a döntéshozók rendkívül nehéz helyzetben vannak, de ha nem történik reagálás a kihívásra, az diszkreditálhatja őket a társadalom és a nemzetközi közvélemény szemében.

Kiss Álmos Péter $A$ hibrid hadviselés természetrajza című munkájában alapvetően helyesen fogalmazta meg, hogy „a ma alkalmazott döntéshozatali és válságreagálási rendszerek nagy része nem képes lépést tartani a váratlan eseményekkel, és nem képes hatékonyan válaszolni azokra". ${ }^{20}$ Megítélésem szerint ez rövid távon igaz, hoszszabb távon viszont egy felelős kormány és egy kompetens állami bürokrácia képes lehet olyan intézkedéseket megvalósítani, amelyek a társadalmat megerősítik, önvédelmi képességét fejlesztik, és a hibrid fenyegetések táptalaját jelentő törésvonalak felett olyan szilárd hidat képeznek, amely a nehéz időkben is összetartja a nemzetet, és minden más nézetkülönbség mellett egy közös nevezőt képeznek az emberek gondolkodásában, amely a hazugságkampányokkal szemben is védelmet jelenthet.

A „fake news” nemcsak azzal rombolja a közösséget, hogy megalapozatlan politikai döntések meghozatalához vezet, hanem gyülöletet is kelthet, amely a társadalom kohézióját csökkenti, továbbá egy járványhelyzetben terjesztett valótlan tájékoztatás a polgárok egészségét és életét is veszélybe sodorhatja. A megtévesztés távlatilag a polgároknak a sajtóba, az intézményekbe, a közigazgatásba és végső soron a demokráciába vetett bizalmát is megingathatja.

Ne feledkezzünk el a hazafias és honvédelmi nevelés fontosságáról sem, mert a pedagógusok tudják megvalósítani az álhíresztelésekkel szembeni immunitás alapkövének letételét az érzelmi intelligencia és a kritikus gondolkodás fejlesztésével, leg-

18 Trump defends calling coronavirus the 'Chinese virus'. 2020. Elérhető: www.aljazeera.com/program$\mathrm{mes} /$ newsfeed/2020/03/trump-defends-calling-coronavirus-chinese-virus-200323102618665.html (A letöltés dátuma: 2020. 04. 28.)

19 Pepe Escobar: China locked in hybrid war with US. 2020. Elérhető: https://asiatimes.com/2020/03/ china-locked-in-hybrid-war-with-us/ (A letöltés dátuma: 2020. 04. 28.)

20 Kiss Álmos Péter: A hibrid hadviselés természetrajza. Honvédségi Szemle, (2019), 4. 17-37. 
inkább ők tudják erősíteni fiataljainkban korunk veszélyeinek felismerési képességét. Tudjuk, hogy abszolút biztonság nincs, de a társadalomnak az előtte álló próbatételekre való felkészítéséért sosem késő tenni.

A jelenlegi világjárvány országonkénti kezelése tapasztalatainak összegzése, illetve elemzése fontos tudást adhat az államok vezetőinek. A mai globalizált világban természetes, hogy valamennyi ország kormánya figyeli a többi ország vezetését, hogy mikor és milyen védelmi intézkedéseket hoznak, másoknál hogyan müködik a védelmi igazgatás rendszere, vagy hogy milyen a jogszabályi környezet. De ez a figyelem azok részéról is megvan, akik a jelenlegi helyzet apropóján felmérik az adott ország gyenge pontjait. Biztos, hogy látni fogják a nehézkes, bürokratikus állami eljárásokat, az elkényelmesedett védelmi szerkezetek lassúságát. Fontos, hogy körültekintően értékeljük a hazai és nemzetközi tapasztalatokat és a hátország civil lakosságát védő rendszert megerősítsük, mert attól tartok, hogy a jövő tele lesz még a jelenleginél is nagyobb kihívásokkal.

\section{Irodalomjegyzék}

Escobar, Pepe: China locked in hybrid war with US. 2020. Elérhető: https://asiatimes.com/2020/03/ china-locked-in-hybrid-war-with-us/ (A letöltés dátuma: 2020. 04. 28.)

Felgenhauer, Pavel: A New Version of the 'Gerasimov Doctrine’?, Eurasia Daily Monitor, 16. (2019), 32. Elérhető: https://jamestown.org/program/a-new-version-of-the-gerasimov-doctrine/ (A letöltés dátuma: 2020. 04. 22.)

Jójárt Krisztián: A hibrid hadviselés és a jövő háborúja. Honvédelmi Szemle, 148. (2020), 1. 5-19. DOI: https://doi.org/10.35926/HSZ.2020.1.1

Kiss Álmos Péter: A hibrid hadviselés természetrajza. Honvédségi Szemle, (2019), 4. 17-37.

Lind, William S.: The Changing Face of War: into the Fourth Generation. Marine Corps Gazette, 73. (1989), 10. 22-26.

A médiahatóság mozgástere az internetes felületeken megjelenö álhírek vagy gyülöletkeltö tartalmak esetén, különösen választási kampány idején. 2018. NMHH Médiajogi háttéranyag. Elérhető: http://nmhh.hu/cikk/194513/A_mediahatosag_mozgastere_az_internetes_feluleteken_megjeleno_alhirek_vagy_gyuloletkelto_tartalmak_eseten_kulonosen_valasztasi_kampany_idejen (A letöltés dátuma: 2020. 04. 22.)

Resperger István: A válságkezelés és a hibrid hadviselés. Budapest, Dialóg Campus, 2018.

A Régiók Európai Bizottsága véleménye - Európai megközelítés az online dezinformáció kezelésére (2019/C 168/04)

Simicskó István: A hibrid hadviselés előzményei és aktualitásai. Hadtudomány, (2017), 3-4. 3-16.

Szun-Ce: A hadviselés törvényei. (Fordította: Tőkei Ferenc) Elérhető: https://mek.oszk. hu/01300/01345/01345.htm (A letöltés dátuma: 2020. 04. 22.)

Tájékoztató az új koronavírusos (Covid-19) megbetegedésekkel kapcsolatban. 2020. Elérhető: https:// konzuliszolgalat.kormany.hu/koronavirus (A letöltés dátuma: 2020. 04. 27.)

Trump defends calling coronavirus the 'Chinese virus.' 2020. Elérhető: www.aljazeera.com/programmes/newsfeed/2020/03/trump-defends-calling-coronavirus-chinese-virus-200323102618665. html (A letöltés dátuma: 2020. 04. 28.) 
Valerij Geraszimov Orosz Hadtudományi Akadémián (Академия военных наук Российской Федерации) elhangzott beszéde. Krasnaya Zvezda, 2019. 03. 04. Elérhető: http://redstar.ru/vektory-razvitiya-voennoj-strategii/?attempt=2 (A letöltés dátuma: 2020. 04. 28.)

\section{Jogi forrás}

A védelmet nyújtó Európa: az Unió a reziliencia kialakitására és a hibrid fenyegetésekkel szembeni hatékonyabb fellépésre törekszik. 2018. Elérhető: https://ec.europa.eu/commission/presscorner/ detail/hu/IP_18_4123 (A letöltés dátuma: 2020. 04. 27.)

Közös közlemény az Európai Parlamentnek és a Tanácsnak: A hibrid fenyegetésekkel szembeni fellépés közös kerete. Európai Bizottság, Brüsszel, 2016. április 6. Elérhető: https://eur-lex.europa.eu/ legal-content/HU/TXT/PDF/?uri=CELEX:52016JC0018\&from=EN (A letöltés dátuma: 2020. 04. 22.)

T/9790. számú törvényjavaslat indokolása. Elérhető: www.parlament.hu/irom41/09790/09790.pdf (A letöltés dátuma: 2020. 04. 27.) 